\title{
Spirometri i allmennpraksis i Nord-Norge
}

\begin{abstract}
Sammendrag
Bakgrunn. Helse- og omsorgsdepartementet har utarbeidet en tiltaksplan for kols (Nasjonal strategi for KOLS-området, 2006-11). Allmennlegene har her en viktig rolle og sentralt står lungefunksjonsmåling, spirometri. Vi ønsket å se nærmere på utbredelsen av spirometri i allmennpraksis i de tre nordligste fylkene.
\end{abstract}

Materiale og metode. Et spørreskjema ble sendt til alle legekontorene i landsdelen. De som ikke returnerte svarskjemaet, ble ringt til og skjemaet ble fylt ut over telefon. Tall på legenes takstbruk knyttet til spirometri (507c) ble innhentet fra NAV.

Resultater. Vi fant at $91 \%$ av legekontorene hadde spirometer. På $66 \%$ av kontorene var det hjelpepersonell som utførte spirometri. $86 \%$ av dem som utførte spirometri, hadde fått opplæring i løpet

av de to siste årene. Om lag $70 \%$ av legene brukte spirometri i sin praksis. Det har vært en økning i bruk fra 2006 til 2007.

Fortolkning. Spirometri er utbredt i allmennpraksis og utføres oftest av hjelpepersonell. Tiltak for å sikre kvaliteten på målingen bør rettes både mot leger og hjelpepersonell.

\author{
Lisa Joensen \\ lisa.joensen@uit.no \\ Hasse Melbye \\ Allmennmedisinsk forskningsenhet \\ Institutt for samfunnsmedisin \\ Universitetet i Troms $\varnothing$ \\ 9037 Tromsø
}

Kronisk obstruktiv lungesykdom (kols) er en hyppig sykdom i befolkningen. Prevalenstall varierer. En metaanalyse publisert i 2006 viste en prevalens på $9-10 \%$ for aldersgruppen over 40 år (1). I Bergensområdet er det funnet en prevalens på $8,3 \%$ for kols stadium II-IV (2). Det forventes økt forekomst av kols, med følgende økt morbiditet og mortalitet (3).

Med bakgrunn i omfang, forventet økt forekomst, samt utfordringene knyttet til diagnostisering og behandling av kols, har Helse- og omsorgsdepartementet laget Nasjonal strategi for KOLS-området (4). Allmennlegene har her en viktig rolle både når det gjelder diagnostisering, behandling og oppfølging av disse pasientene. Sentralt i dette arbeidet står lungefunksjonsmåling, spirometri. I tillegg til å diagnostisere kols og andre lungesykdommer brukes spirometri til å angi alvorlighetsgrad, og er dermed veiledende for behandling. De nye reglene i blåreseptforskriften fra 1.7.2007, stiller krav til bruk av spirometri for verifisering av diagnose og sykdomsstadium før forskrivning av medikamenter til kolspasienter.

I vår studie ønsket vi å se på hvor mye spirometri ble brukt $\mathrm{i}$ allmennpraksis $\mathrm{i}$ de tre nordligste fylkene, samt hvordan legekontorene organiserte gjennomføring av målingen på legekontoret.

\section{Materiale og metode}

Vi fant kontaktinformasjon til alle fastlegekontor i Nordland, Troms og Finnmark på NAVs nettside (5). Fra NAV fikk vi også informasjon om bruk av takst 507c (spirometritaksten) blant fastlegene (tall gitt per e-post fra Anne Sagsveen, NAV). Befolkningstall ble innhentet fra nettsiden til Statistisk sentralbyrå (6).

Det ble sendt kun ett spørreskjema til hvert legekontor, sammen med informasjon om undersøkelsen og adressert svarkonvolutt. Innholdet i spørreskjemaet er angitt i tabell 1. De legekontorene som ikke hadde returnert skjemaet innen seks uker, ble oppringt og skjemaet ble fylt ut per telefon på grunnlag av opplysninger fra lege eller helsesekretær, hovedsakelig helsesekretær.
Legekontorene ble spurt om spirometeret fremstilte spirometrikurver, dette for å få greie på om de hadde oppdatert utstyr.

Anvendelse av spirometri og prosedyrer knyttet til slik bruk på legekontoret ble registrert. Forskjeller mellom fylkene ble analysert ved khikvadrattest, der $\mathrm{p}$-verdi $<0,05$ ble vurdert som statistisk signifikant. For de statistiske analyser brukte vi SPSS 15.0 for Windows. Undersøkelsen er godkjent av Personvernombudet for forskning, NSD (Norsk samfunnsvitenskapelige datatjeneste).

\section{Resultater}

Det ble sendt ut 183 skjemaer. Etter seks uker hadde 131 legekontor svart. 14 av adressene viste seg å være kontor som hadde flyttet, utekontor sjeldent betjent eller adressat ukjent. Reelt var det således 169 kontor vi kunne forvente å få svar fra. Etter seks uker hadde vi en svarprosent på 77. Etter oppringing og utfylling av skjemaet per telefon hadde vi svar fra 167 legekontor. Et kontor ønsket ikke å delta og et annet var lite tilgjengelig på telefon. Til sammen hadde vi da svar fra $98 \%$ av kontorene vi kunne forvente å få svar fra. Kun tre av de 150 legekontorene som hadde spirometer, fikk ikke fremstilt spirometrikurver.

Resultatene er fremstilt i tabell 1. 90,9\% av legekontorene hadde spirometer. Det var oftere hjelpepersonell enn leger som utførte spirometri og omtrent halvparten av personell som utførte slik måling hadde fått opplæring for mindre enn to år siden. Tallene viser at det er forskjell mellom fylkene når det gjelder hvor mange legekontor som har spirometer, hvem som utfører undersøkelsen og hvordan opplæringen organiseres.

Finnmark skilte seg ut ved å være det

\section{Hovedbudskap}

- Bruk av spirometri er utbredt i allmennpraksis

- Det er forskjeller i hvordan legekontorene organiserer utførelsen. Oftest er det hjelpepersonell som foretar slik lungefunksjonsmåling

- Opplæring av personell foregår både internt på kontoret og på eksterne kurs

- Nærmere studier av kvaliteten på spirometri utført i allmennpraksis bør vurderes samt hvordan forskjeller i praksis virker inn 
Tabell 1 Fylkesvis og samlet oversikt over utbredelse av spirometri, prosedyrer ved bruk samt opplæring av dem som betjener spirometeret

\begin{tabular}{|c|c|c|c|c|c|c|c|c|}
\hline & \multicolumn{2}{|c|}{ Nordland } & \multicolumn{2}{|c|}{ Troms } & \multicolumn{2}{|c|}{ Finnmark } & \multicolumn{2}{|c|}{ Samlet } \\
\hline & $n$ & (\%) & $n$ & $(\%)$ & $n$ & $(\%)$ & $n$ & $(\%)$ \\
\hline \multicolumn{9}{|l|}{ Kommunestørrelse } \\
\hline Med sykehus & 41 & $(44,1)$ & 18 & $(37,5)$ & 4 & $(16,7)$ & 63 & $(38,2)$ \\
\hline Uten sykehus & 52 & $(55,9)$ & 30 & $(62,5)$ & 20 & $(83,3)$ & 102 & $(61,8)$ \\
\hline \multicolumn{9}{|l|}{ Spirometer på legekontoret } \\
\hline Har spirometer & 82 & $(88,2)$ & 44 & $(91,7)$ & 24 & $(100)$ & 150 & $(90,9)$ \\
\hline Har ikke spirometer & 11 & $(11,8)$ & 4 & $(8,3)$ & 0 & (0) & 15 & $(9,1)$ \\
\hline \multicolumn{9}{|l|}{ Undersøkelsesstilling } \\
\hline Stående & 47 & $(50,5)^{1}$ & 15 & $(31,3)$ & 9 & $(37,5)$ & 71 & $(43,1)$ \\
\hline Sittende & 26 & $(28,0)$ & 25 & $(52,1)$ & 5 & $(20,8)$ & 56 & $(33,9)$ \\
\hline Begge deler & 8 & $(8,6)$ & 3 & $(6,3)$ & 8 & $(33,3)$ & 19 & $(11,5)$ \\
\hline Ikke besvart spørsmålet & 12 & $(12,9)$ & 5 & $(10,4)$ & 2 & $(8,3)$ & 19 & $(11,5)$ \\
\hline \multicolumn{9}{|l|}{ Hvem utfører spirometri? } \\
\hline Lege & 22 & $(23,7)^{2}$ & 5 & $(10,4)$ & 1 & $(4,2)$ & 28 & $(17,0)$ \\
\hline Hjelpepersonell & 54 & $(58,1)$ & 34 & $(70,9)$ & 21 & $(87,5)^{3}$ & 109 & $(66,0)$ \\
\hline Både lege og hjelpepersonell & 6 & $(6,4)$ & 5 & $(10,4)$ & 1 & $(4,2)$ & 12 & $(7,3)$ \\
\hline Ikke besvart spørsmålet & 11 & $(11,8)$ & 4 & $(8,3)$ & 1 & $(4,2)$ & 16 & $(9,7)$ \\
\hline \multicolumn{9}{|l|}{ Hvordan er opplæring gjort? } \\
\hline Internt på legekontoret & 16 & $(17,2)$ & 7 & $(14,6)$ & 14 & $(58,3)^{4}$ & 37 & $(22,4)$ \\
\hline På eksterne kurs & 23 & $(24,7)$ & 20 & $(41,7)$ & 7 & $(29,2)$ & 50 & $(30,3)$ \\
\hline Både internt og eksternt & 28 & $(30,1)$ & 14 & $(29,2)$ & 1 & $(4,2)$ & 43 & $(26,1)$ \\
\hline Ikke besvart spørsmålet & 26 & $(28,0)$ & 7 & $(14,6)$ & 2 & $(8,3)$ & 35 & $(21,2)$ \\
\hline \multicolumn{9}{|l|}{ Når ble opplæring sist gitt? } \\
\hline For mindre enn 2 år siden & 43 & $(46,2)$ & 31 & $(64,6)$ & 12 & $(50,0)$ & 86 & $(52,1)$ \\
\hline For mer enn 2 år siden & 23 & $(24,7)$ & 9 & $(18,8)$ & 8 & $(33,3)$ & 40 & $(24,2)$ \\
\hline Varierer mellom ansatte & 2 & $(2,2)$ & 1 & $(2,1)$ & 2 & $(8,3)$ & 5 & $(3,0)$ \\
\hline Ikke besvart spørsmålet & 25 & $(26,9)$ & 7 & $(14,6)$ & 2 & $(8,3)$ & 34 & $(20,6)$ \\
\hline
\end{tabular}

Spirometri utføres oftere i stående stilling i Nordland sammenliknet med i Troms og Finnmark, $p<0,05$

${ }^{2}$ Lege utfører oftere spirometri i Nordland sammenliknet med i Troms og Finnmark, $p<0,05$

3. Finnmark utføres spirometri oftere av hjelpepersonell sammenliknet med i Troms og Nordland, $p<0,05$

${ }^{4}$ | Finnmark gis opplæring oftere internt på kontoret sammenliknet med $i$ Troms og Nordland, $p<0,05$

fylke der alle legekontor hadde spirometer. Her var det oftest, hos $87,5 \%$, hjelpepersonell som utførte spirometri. $58 \%$ av dem hadde fått opplæring internt på legekontoret. Den laveste andel av legekontor med spirometer ble funnet i Nordland. Her ble flere spirometrier, $23,3 \%$, foretatt av lege, og halvparten av spirometriene ble utført med pasienten i stående stilling.

I alle fylkene har det vært en økning i bruk av spirometri per 1000 innbygger fra 2006 til 2007, i Nordland fra 33 til 35, i Troms fra 23 til 26 og i Finnmark fra 20 til 26. Landsgjennomsnittet for antall spirometrier utført per 1000 innbygger var i 2007 på 35. Tallene for spirometri og befolkningstall for 2007 er fremstilt i tabell 2. I 2007 brukte ca. $70 \%$ av legene spirometritaksten, det var

Tabell 2 Oversikt over legers bruk av spirometri i de ulike fylkene, antall spirometrier per lege og per innbygger i 2007

\begin{tabular}{llll} 
& Nordland & Troms & Finnmark \\
Totalt antall leger & 453 & 290 & 191 \\
\hline Antall leger som utførte spirometri & 322 & 209 & 132 \\
\hline Andel leger som utførte spirometri (\%) & 71,1 & 72,1 & 69,1 \\
\hline Totalt antall spirometrier & 8247 & 3962 & 1875 \\
\hline Antall spirometrier per lege & 25,6 & 18,9 & 14,2 \\
\hline Folketall & 235436 & 154136 & 72665 \\
\hline Antall spirometrier per 1000 innbyggere & 35 & 26 & 26
\end{tabular}

liten forskjell mellom fylkene. I Nordland utføres det flest spirometrier både per lege og per 1000 innbyggere.

\section{Diskusjon}

Vi har ikke funnet andre studier som har svar på bruken av spirometri fra så å si alle legekontor i en landsdel. I studier på utvalg av legekontor i Sverige og Danmark fant man at $85-95 \%$ av legene i allmennpraksis hadde spirometer $(7,8)$. Således synes de skandinaviske landene å ha en del fellestrekk når det gjelder bruk av spirometri i allmennpraksis.

Det har vært reist spørsmål om hvorvidt det finnes nok kompetanse på allmennlegekontorene til å utføre spirometri. Undersøkelse med spirometer har flere komponenter som kan være mulige feilkilder: utstyr, kompetanse hos personell som utfører undersøkelsen, teknikk hos pasient og kunnskap hos den som tolker resultatet (9).

Opplæring og jevnlig trening er nødvendig for å opprettholde tilfredsstillende kvalitet på undersøkelsen $(10,11)$. Studier viser at kvaliteten på spirometri utført i primærhelsetjenesten varierer. Ved én undersøkelse fant man dårlig samsvar mellom resultat av spirometri foretatt på henholdsvis allmennlegekontor og lungeavdeling på sykehus (12). Andre derimot, har funnet at spirometri i allmennpraksis gir valide resultater, vel å merke etter gjennomført standardisert opplærings- og treningsprogram for dem som utfører undersøkelsen (13).

Helse- og omsorgsdepartementet ønsker å vurdere behov for opplæring av personell og utarbeiding av nasjonale retningslinjer $\mathrm{i}$ bruk av spirometri (4). I Finland gjorde man i 1990-årene en «kvalitetsmåling» av spirometri på landsbasis og fant at kvaliteten ikke var tilfredsstillende. Man utarbeidet derfor nasjonale retningslinjer for gjennomføring av spirometri. Evalueringen tre år senere viste at kvaliteten var blitt bedre (14).

Vi har ikke hentet inn informasjon som kan si noe om kvaliteten på spirometri i allmennpraksis eller innholdet $\mathrm{i}$ opplæringen av personell som utfører spirometri. At en del legekontor utfører spirometri med pasienten i stående stilling, kan dog tyde på at de ikke kjenner til standardiserte prosedyrer, der det anbefales at pasienten undersøkes $\mathrm{i}$ sittende stilling (15).

Vår undersøkelse viser at spirometri er utbredt i allmennpraksis. Dette er i tråd med nasjonale tiltaksplaner. Tallene innhentet fra NAV angående takstbruk viser økt bruk av spirometri. Dette ble også nylig påvist $\mathrm{i}$ en studie fra Trøndelag (16). Det er grunn til å tro at bruken fortsatt vil øke, både på grunn av endring i refusjonsreglene for medikamenter, og på grunn av økonomiske incitamenter i form av økte takster for bruk av spirometri. Det er ulik praksis på legekontorene med hensyn til hvem som utfører spirometri og hvordan opplæringen er organisert. Vi vet ikke hvordan dette påvirker kvaliteten på 
undersøkelsene, videre studier vil derfor være nyttig. Nasjonale retningslinjer vektlegger kompetanseheving hos allmennlegene (4). Ettersom det oftest er hjelpepersonell som utfører spirometri, er det viktig å sikre kompetanseheving også for dem.

Oppgitte interessekonflikter: Ingen

\section{Litteratur}

1. Halbert RJ, Natoli JL, Gano A et al. Global burden of COPD: systematic review and meta-analysis. Eur Respir J 2006; 28: 523-2

2. Buist AS, Mc Burnie MA, Vollmer WM et al. International variation in the prevalence of COPD lthe BOLD Study): a population-based prevalence study. Lancet 2007; 370: 741-750.

3. Murray CJ, Lopez AD. Alternative projections of mortality and disability by cause 1990-2020: Global Burden of Disease Study. Lancet 1997; 349. $1498-504$.

4. Nasjonal strategi for KOLS-området 2006-2011. Oslo: Helse- og omsorgsdepartementet, 2006.

5. NAV. www.nav.no (5.10.2007)

6. Statistisk sentralbyrå. www.ssb.no (10.9.2008).

7. Thorn J, Norrhall M, Larsson R et al. Management of chronic obstructive pulmonary disease (COPD) in primary care: a questionnaire survey in western Sweden. Prim Care Respir J 2008; 17: 26-31.

8. Lange P, Rasmussen FV, Borgeskov $\mathrm{H}$ et al. The quality of COPD care in general practice in Denmark: the KVASIMOD study. Prim Care Respir J 2007; 16: 174-81.

9. Derom E, van Weel C, Liistro $G$ et al. Primary care spirometry. Eur Respir J 2008; 31: 197-203.

10. Eaton T, Withy S, Garrett J E et al. Spirometry in primary care practice: the importance of quality assurance and the impact of spirometry workshops. Chest 1999: 116: 416-23.

11. Miller MR, Crapo R, Hankinson J et al. General considerations for lung function testing. Eur Respir J 2005; 26: 153-61.

12. Akhtar R, Wilson A. A comparison of spirometry between general practice and a pulmonary func tion laboratory. Prim Care Respir J 2005; 14 215-220.

13. Shermer TR, Jacobs JE, Chavannes NH et al. Validity of spirometric testing in a general practice population of patient with chronic obstructive pulmonary disease. Thorax 2003; 58: 861-6.

14. Piirilä P. Pietinalho A, Loponen M et al. The quality of spirometric examinations in Finland: results from a national questionnaire survey. Clin Physiol Funct Imaging 2002; 22: 233-9.

15. Miller MR, Hankinson J, Brusasco V et al. Standardisation of spirometry. Eur Respir J 2005; 26: 319-38.

16. Haugan T, Bakken IJ, Storrø 0 et al. Utvikling i diagnostisering og helsetjenesteforbruk ved obstruktiv lungesykdom. Tidsskr Nor Legeforen 2008; 128 : $2431-4$

Manuskriptet ble mottatt 6.2. 2009 og godkjent 22.10. 2009. Medisinsk redaktør Are Brean. 